Journal of Southeast Asian Studies, 38(3), pp 541-558 October 2007. Printed in the United Kingdom.

(C) 2007 The National University of Singapore doi:10.1017/S0022463407000252

\title{
'Seats for spirits to sit upon': Becoming a spirit medium in contemporary Vietnam
}

\author{
Nguyễn Thị Hiền
}

This article will examine the motivations for being spirit mediums, practitioners of the lên đồng rituals associated with the Mother Goddess (Đạo Mẫu) religion, which is unique to the ethnic Vietnamese. Drawing on the life stories of mediums interviewed in northern Vietnam, I will show that these people practise the rituals primarily because they themselves view this role as their destiny and because they expect it to bring them good health and auspiciousness.

There are some common and interesting expressions among lay people that seem to capture Vietnamese society's negative attitude towards mediums: ‘đồ đồng bóng' ('you medium!'), and 'trông đồng bóng' (to look like a medium). To be said to be like or look like a medium implies character traits such as a hot temper, moodiness or fickleness in relationships with others. These expressions are also used to refer to people who, according to others, dress colourfully and oddly. Husbands also use the term 'bà đồng' (female spirit medium) to tease their wives when they get irritable and angry. Lately, 'đồ đồng bóng' and 'trông đồng bóng' have become popular expressions to describe people with impulsive natures and colourful clothes. Critics of the lên đồng (spirit possession) ritual in the media and government regard it as superstitious, frivolous and wasteful. ${ }^{1}$ From the point of view of a large part of Vietnamese society, mediums are superstitious folk, who dance wildly ( nhảy nhót) wearing colourful costumes (ãn măc loè loẹt) and have 'silly beliefs' ( tin vó vẩn) in supernatural powers. While social prejudices make a number of mediums reluctant to speak out about their status and compel them to be somewhat discreet and even secretive about their practice, more people across the social spectrum are being initiated and performing lên đồng rituals.

Nguyễn Thị Hiền is a researcher with the Department of Intangible Cultural Heritage in the Institute of Culture and Information Studies of the Ministry of Culture and Information, Hanoi. Correspondence in connection with this paper should be addressed to: hiennguyenb@yahoo.com.

The data of this paper mainly comes from a chapter of my doctoral dissertation: 'The religion of the Four Palaces: Mediumship and therapy in Viet culture (Indiana University, 2002). The title 'Seat for spirits to sit upon' [Bắc ghế cho các ngài ngụ] is taken from the words pronounced by mediums to express their intention to serve the spirits and to perform lên đồng (possession) rituals.

I would like to express my sincere thanks to Laurel Kendall, Karen Fjelstad, Oscar Salemink and Bruce Lockhart for their comments and input. I am especially indebted to my informants, who have provided me tremendous assistance in doing fieldwork and insight into their beliefs and rituals. Without their help, this research would have been impossible.

1 Trương Thìn, 'Tôn trọng tín ngưỡng và bài trừ mê tín dị đoan' [Respect religious beliefs and abolish superstitions], in Tín nguỡng mê tín [Religious beliefs - superstition], ed. Hà Văn Tăng and Trương Thìn (Hanoi: Thanh niên, 1998), pp. 112-26. 
The question of why women and men become bà đồng and ông đồng (female and male spirit mediums respectively) has not received sufficient attention in scholarly literature. This article will examine the motivations for being spirit mediums, that is, the personal journeys they undertake to become 'seats for spirits to sit upon' (bắc ghế cho các ngài ngụ). Although popular opinion regards spirit mediums as superstitious people, the women and men described here are better characterised as practitioners of a possession ritual that enacts the beliefs of the Mother Goddess religion (Đạo Mẫu), a religion unique to the Viet (ethnic Vietnamese). Drawing on life stories and interviews of mediums ${ }^{2}$ during my fieldwork in the past few years in Hanoi, Hưng Yên, Hải Dương, Thái Bình and Nam Định provinces, I will show that these people practise lên đồng primarily because they themselves view it as their destiny and because they expect their practice to bring them good health and auspiciousness. ${ }^{3}$

Many studies have argued that possession is a cult for women; lower-class, subordinate or deviant groups and individuals; or people with emotional troubles or mental or physical illness. In fact, however, spirit possession is a complicated ritual and cannot be reduced simply to western medical terms, as in the works of those who would argue that possession is 'induced by individuals' stress' ${ }^{4}$ Karen Fjelstad, who has studied the Mother Goddess religion in California within the context of health-care resources, sees it as representing those worldviews which are culturally defined as female. More broadly, Ioan Lewis has claimed that spirit possession is a form of illness that typically afflicts women and other individuals of marginal or subordinate status. Gananth Obeyesekere and Janice Boddy have maintained that the possessed are unwell, clearly troubled women, while Bruce Kapferer has argued that their femininity culturally prefigures them as being prone to demonic attack. ${ }^{5}$ In these and other cases, possession has often been interpreted as a ritual for therapeutic values, a means of

2 Among these mediums, my main consultant was Sister (Chi) Nga, a master medium (đồng trương) who lived in a village near mine in Văn Giang district of Hưng Yên province. She has inspired me to study the Mother Goddess religion and lên đông rituals. She was eager to recall for me her miserable childhood and her experience with knotted hair, a phenomenon I would come to know well. Nga also spoke openly to me of her life as a medium - how she had cured hundreds of patients by praying to spirits of the Mother Goddess religion, anointing them with holy water mixed with the ashes from burned incense and initiating them into her faith.

3 In this article 'auspiciousness' denotes good health, a good life and prosperity. The interpretation of lên đồng as a practice meant to achieve well-being and economic success is found in several chapters of a recently published volume on Vietnamese mediums: Phạm Quỳnh Phương, 'Trần Hưng Đạo and the Mother Goddess religion'; Karen Fjelstad and Lisa Maiffret, 'Gifts from the spirits: Spirit possession and personal transformation among Silicon Valley spirit mediums'; and Viveca Larsson and Kirsten Endres, 'Children of the spirits, followers of a master: Spirit mediums in post-Renovation Vietnam', in Possessed by the spirits: Mediumship in contemporary Vietnamese communities, ed. Karen Fjelstad and Nguyễn Thị Hiền (Ithaca: Cornell Southeast Asia Program, 2006), pp. 31-54, 111-26, and 143-60 respectively. 4 Collen Ward, 'Spirit possession and mental health: A psycho-anthropological perspective', Human Relations, 33, 3 (1980): 149-63.

5 Karen Fjelstad, 'Mother Goddess religion cong dong: Vietnamese women and mediumship in the San Francisco Bay area' (Ph.D. diss., University of Hawaii, 1995); Ioan Lewis, Ecstatic religion: A study of spirit possession and shamanism, $2^{\text {nd }}$ edn (London: Routledge, 1989); Gananth Obeyesekere, Medusa's hair: An essay on personal symbols and religious experience (Chicago: University of Chicago Press, 1981); Janice Boddy, Wombs and alien spirits: Women, men, and the zar cult in northern Sudan (Madison: University of Wisconsin Press, 1989); Bruce Kapferer, A celebration of demons: Exorcism and healing in Sri Lanka (Washington, DC: Smithsonian Institution Press, 1991). 
easing frustration or a way to achieve power and status within a society or family. Alternatively, the possession is viewed as a peripheral cult resulting from deprivation since in societies 'women are in fact treated as peripheral creatures' ${ }^{6}$

Scholars who have studied lên đồng and Mother Goddess religion in Vietnam and mediumship elsewhere have observed that more women than men are involved in spirit possession rituals. ${ }^{7}$ The fact is, however, that unhealthy and troubled women have received disproportionately greater attention in the literature. More recent and comprehensive studies have argued that spirit possession is shared by men and women, young and old, from a full spectrum of socio-economic backgrounds, including the poor and illiterate and well as people of more substantial means. ${ }^{8} \mathrm{My}$ research supports this view by showing that the religion involves not only troubled or physically or mentally ill people, but also those from the upper class, including wealthy and successful businessmen and businesswomen expecting worldly gain. ${ }^{9}$ Their life stories are a helpful method for understanding the religion and its practice from an emic point of view. These stories help us to see how the practitioners themselves perceive and interpret the beliefs of Mother Goddess religion on an everyday basis.

My work follows the principle, 'let those who believe in spirits and possession speak for themselves' ${ }^{10}$ I use my informants' interpretations as a supportive method to understand the living tradition of the popular religion and lên đồng performance. I try to describe those beliefs and practices as they have existed in contemporary Viet culture and as they have been perceived in the minds and thoughts of the local people. This is a method that many other scholars on spirituality have used as well. For instance, Laurel Kendall, in her first book on Korean shamanism, refrains 'from such condescending qualifiers as "Korean women believe, or think, that..." She describes the workings of

6 Ioan Lewis, Ecstatic religion: Religion in context (Cambridge: Cambridge University Press, 1986), p. 42. On the therapeutic value of possession see John Kennedy, 'Nubian zar ceremonies as psychotherapy', Human Organization, 26 (1967): 185-94; and Vincent Crapanzano, The Hamadsha: A study of Moroccan ethnopsychiatry (Berkeley: University of California Press, 1973). The power aspect is discussed in Pham Quỳnh Phương, 'Trần Hưng Đạo' and Susan Kenyon, 'The case of the butcher's wife: Illness, possession and power in central Sudan', in Spirit possession: Modernity and power in Africa, ed. Heike Behrend and Ute Luig (Madison: University of Wisconsin Press, 1999), pp. 89-108.

7 The gender issue is discussed in Barley Norton, "'Hot-tempered" women and "effeminate" men: The performance of music and gender in Vietnamese mediumship' and Kirsten Endres, 'Spirit performance and the ritual construction of personal identity in modern Vietnam', in Possessed by the spirits, ed. Fjelstad and Nguyễn, pp. 55-76 and 77-94 respectively.

8 Kenyon, 'Case of the butcher's wife', pp. 89-90, discusses the broad range of people who engage in mediumship.

9 The importance of wealth and making money in various religious practices, including village festivals, pilgrimages to pagodas, temples and historical sites; and various other rituals, has been discussed in a number of sources. See John Kleinen, Facing the future, reviving the past: A study of social change in a northern Vietnamese village (Singapore: Institute of Southeast Asian Studies, 1999); the articles by Lê Hồng Lý and Oscar Salemink in this issue; Luong Van Hy, 'Economic reform and the intensification of rituals in two north Vietnamese villages, 1980-1990', in The challenge of reform in Indochina, ed. Borje Ljunggren (Cambridge, MA: Harvard Institute for International Development, 1993), pp. 259-92; Ngô Đức Thinh, 'The belief in the Granary Queen and the transformation of Vietnamese society' (Hanoi: Viện Nghiên cứu Văn hoá Dân gian, unpublished paper).

10 Lewis, Ecstatic religion: A study, p. 25. 
the supernatural as they were described to her, rendering a belief system in its own terms. ${ }^{11}$ I also describe the stories and phenomena as they are told to me.

Before presenting an ethnographical view on bà đồng and ông đồng, I will provide $\mathrm{a}$ brief discussion on the tenacity of lên đồng rituals that survived during the 'subsidy period' (as the Vietnamese generally refer to the time of socialist central planning) and have become vital today. It was a time when folk beliefs were regarded as backward practices and were officially banned. These restrictions have only been relaxed with the implementation of Đổi Mới (renovation) in Vietnam.

\section{The tenacity of lên đồng rituals}

In Vietnam, the negative official attitude towards spirit mediums, mediumship and other folk practices and rituals has been concretised by a series of legal documents on these practices. From 1946, when the first constitution affirmed 'freedom of belief (tụ do tín ngương) until renovation (Đổi Mới) in 1986, there was official opposition to religion, including a policy of atheism and an anti-superstition campaign. Furthermore, the ritual practitioners and spirit mediums were described by the media as 'liars and swindlers', 'uneducated, ignorant people'. All rituals and practices that involved supernatural forces to '[deal] with human agonies and anxieties' were abandoned. ${ }^{12}$ Barley Norton and Shaun Malarney have discussed the impact of these official policies on the mediums and other practices of religious specialists. There were also a number of regulations restricting religious and folk cultural practices by reducing the scale of their activities and limiting the numbers of their adherents. ${ }^{13}$ However, these measures did not destroy religion or religious devotion among the Vietnamese, and these beliefs have survived in various forms.

During the period of religious restriction, folk practitioners had had to contend with the central state and its policies while simultaneously negotiating with and even counter-attacking local authorities. In villages where pagodas or temples were destroyed or transformed into rice storage areas, there were many stories circulating which targeted the local officials who had implemented state instructions to dismantle these structures. The consequence of these blasphemous acts was that the officials might become very sick or several of their family members might die within a short time. ${ }^{14}$ One way for mediums to be free of government restrictions was to conceal their rituals and ceremonial paraphernalia. As Norton has observed, they performed quietly

11 Laurel Kendall, Shamans, housewives, and other restless spirits: Women in Korean ritual life (Honolulu: University of Hawaii Press, 1985).

12 Barley Norton, 'Vietnamese mediumship rituals: The musical construction of the spirits', The World of Music, 42, 2 (2000): 76; Endres, 'Children of the spirits', p. 77.

13 Norton, 'Vietnamese mediumship rituals'; Shaun Malarney, Culture, ritual, and revolution in Vietnam (New York: RoutledgeCurzon, 2002).

14 This type of oral narrative is popular in villages where Buddhist pagodas or temples were destroyed. One story in my home village relates the life of the commune head who ordered the villagers to destroy the Buddhist temple complex, implying official instructions to that effect. At that time, villagers took the Buddhist statues to bury them for safekeeping, while others stole objects from the pagoda and took them home for their own use. As a result, years later when the official was retired, he was 'punished' spiritually, the villagers said: he did not go out and only stayed at home beating a wooden $\operatorname{drum}(g \tilde{o} m \tilde{o})$, an act which Buddhist monks and nuns would perform during their ceremonies. The villagers also listed a number of people who had died prematurely for having wrongly appropriated the temple objects. The 
with no music and with limited offerings. ${ }^{15}$ They practised in secret, at night and out of the public and official gaze. Thus, their rituals were less noticeable to the authorities, and they performed when 'policemen went to sleep', as one of my informants commented.

Meanwhile, state policy supported temples dedicated to national and historical heroes who had contributed great merit (công) to the country and people. As Phạm Quỳnh Phương has noted, it was quite understandable that the Mother Goddess religion welcomed the spirit of Trần Hưng Đạo, the general who fought against Mongol invaders in the late thirteenth century. ${ }^{16}$ In recent times, one can also observe the presence of images of Hồ Chí Minh in the temples. This phenomenon can be scrutinised in two ways. Firstly, the fact that the adherents of the Mother Goddess religion install his statue and worship him as a god in their pantheon reveals the Viet tradition of venerating their heroes. Secondly, the presence of the legally recognised figures is to legitimise their worship of other spirits and their practices in general. ${ }^{17}$

Mediums also found logical explanations for their practices by arguing that the veneration of spirits was closely related to the paying of one's respects to one's ancestors and to the Buddha - and therefore that these rituals should be classed not as 'superstition' but on a par with beliefs such as ancestor worship. Even when their identity cards and performing robes were confiscated, they tried their best to debate with the authorities, explaining that they went to pray and perform the rituals because the temples were sacred and beautiful places to visit. ${ }^{18}$ The mediums took every opportunity to convince local officials and government policemen that their practices were worthy of respect. When it became possible for Vietnamese and foreign researchers to observe the rituals, Nga, one of the main informants for my research, really enjoyed taking pictures with them to show her respect and friendship and to demonstrate that her practices were being validated and studied. Another strategy was to spread stories about mediums who performed rituals in secret for higher-ranking cadres and local officials, which was seen as another way to legitimise their practices.

A common way to compromise with the local authorities (including the police) is to develop good and close connections with them to avoid getting into trouble. ${ }^{19} \mathrm{I}$ learned this lesson through my fieldwork and through the experiences of a senior

land where the Buddhist pagoda was situated became a potent sacred (thieng) site where people were reluctant to live or build houses. Only recently, with the dramatic rise in land prices in both urban and rural areas, which has made it difficult for young couples to buy a piece of land for their homes, did anyone risk building on this sacred site. So far, however, I have not heard any stories about 'punishment' as a result of this action. A major regret for the villagers is that they could not afford to build a new temple; instead, they made a very small Buddhist shrine next to the temple dedicated to the village spirit. One of their wishes today is to raise money and to receive government funds to construct a pagoda. 15 Norton, 'Vietnamese mediumship rituals'.

16 On the adaptation of Trần cult into Mother Goddess Religion, see Phạm Quỳnh Phương, 'Trần Hưng Đă丶’

17 Nguyễ் Thị Hiền, 'Spiritual parents of the Viet' (paper read at the AAS Annual Meeting, 2003); Phạm Quỳnh Phương, 'Hero and deity: Empowerment and contestation in the veneration of Trần Hưng Đạo in contemporary Vietnam' (Ph.D. diss., La Trobe University, 2005).

18 Larsson and Endres, 'Children of the spirits'.

19 Religious practice as a dialogue between the state and local levels is mentioned by Philip Taylor, Goddess on the rise: Pilgrimage and popular religion in Vietnam (Honolulu: University of Hawaii Press, 2004), p. 6. 
colleague at the Institute of Cultural Studies in Hanoi. It is worth pointing out here that with local connections I was freed of the requirement to submit documents for permission to do fieldwork on religious practices. This strategy of building relationships proved very valuable when it was successfully applied to help my informant Nga get out of trouble. One evening I received a call from Nga, who gave me the following account in a shaky voice:

He (a village policeman) came back to me in the late afternoon after you left. He gave me a warning summoning me to the communal People's Committee headquarters (Uỷ ban Nhân dân Xã) tomorrow. I am afraid that they (the local authorities) will stop my practice. In a week, I will have an initiation ritual for my older daughter. Her life is miserable (khổ lăm), as she got divorced, then remarried, then divorced again. Her business is going downhill. She would like to be initiated to serve the spirits for a better life. You are out there in Hanoi. You have been around the country and abroad (nước ngoài nước trong) and done your research on lên đồng with international scholars. Please do something for us. You may obtain a permission letter there for me to practice. I am down here, having a lot of trouble. The commune police (công an $x \tilde{a}$ ) sometimes come to disturb me. ${ }^{20}$

Nga called me because it was my foreign colleagues and I who had stirred up her peaceful practice. On 28 August 2003, she performed a (tái khoá) re-initiation ritual that was conducted when the first initiation of a novice did not turn out well. I brought with me an American, a Korean and a Vietnamese scholar of shamanism to observe her ritual in a village 20 kilometres southeast of Hanoi. Because of some piles of construction sand and bricks and a heavily loaded truck, our car could not get through the village lane to her shrine, and we had to walk there. We were seen by a number of villagers, and it was reported to the local authorities that some foreigners had entered the village without permission. A lot of suspicious rumours circulated that they could be Christian missionaries who had come to eradicate the traditional beliefs of the village. The main issue was that foreigners should report their presence and the purpose of their visit to the local authorities, who would then accompany them to the places they were visiting.

In the middle of the ritual in that day, a policeman came to see what was going on. Nga's husband was scared to death and intended to give to him a bribe of 200,000 đồng (equal to US\$16 at the time), but then he was advised that he should not, and so he just offered the policeman some cigarettes. When the ritual was over and we and other participants had gone, that policeman returned and gave Nga a written summons to appear at the commune office the following morning. She was frightened, wishing that in the morning her husband had gone ahead and offered the policeman the bribe, which would have allowed a peasant to live on rice and vegetables for a month. During our telephone conversation, Nga added that the policeman had warned her that lên đồng and divination sessions were banned, although she and other practitioners still conducted their rituals, because local authorities had so far disregarded them. On that 
day, however, the presence of foreigners stirred things up in this quiet and peaceful village.

My informant kept calling, counting on me to do something on her behalf. Her calls encouraged me to talk with a senior researcher on religious practices to interpret what was going on between the authorities and practitioners, but he just laughed and did not give me any clear advice. I suggested to Nga that she should meet with the local officials and police to make closer connections and to gain their support, as Vietnamese people normally do to avoid red tape. I reaffirmed that this was the best solution at the time. I also told her that even my own research on lên đồng spirit possession was not officially presented as such; rather, when I applied for permission to take videotapes and cassettes of rituals with me to the United States, I had claimed to be working on 'cultural traditions'. The question of legitimisation in the field of folk rituals concerns not only practitioners looking for ways to evade political restrictions, but also researchers who seek to have their work legitimised. Nga followed my advice about building better relations with local authorities; as a result, she was able to resume her practice in one week and performed the initiation ritual for her own daughter as scheduled.

Since the 1980s, when the state launched the reforms to move toward a market economy, Vietnam has witnessed the relaxation of restrictions and the development of a religious consciousness in the form of traditional folk practices, including village festivals, local and family religious rituals, ceremonies and folk musicals and performing arts. Among the diverse folk traditions, lên đồng has become a 'widely accepted, widespread and very popular practice'. ${ }^{21}$ However, at the time when Đổi Móri began, the state still exercised tight control over groups of Buddhists, Catholics, Protestants and folk practitioners. A number of prominent folk practitioners and individuals from various institutionalised religions were arrested. The tremendous change in folk rituals and practices actually occurred when the veneration of spirits was granted equal rights with the worship of historical figures in the newly issued ordinance on folk beliefs and religion. This document was passed by the Standing Committee of the National Assembly on 18 June 2004 and took effect in mid-November. In the document, Item 1 of Article 3 recognises folk belief activities, including ancestor worship, the commemoration of historical figures and the veneration of spirits. ${ }^{22}$

Today, going to pray in Buddhist pagodas and temples of the Mother Goddess religion is becoming so popular that people may be surprised to meet someone who

21 Phan Đăng Nhật and Oscar Salemink, 'Ritual transformations around a spirit medium in the northern highlands of Vietnam', paper read at the Second International Conference on Vietnamese Studies, Hồ Chí Minh City, 2004, p. 6. On the revitalisation of lên đồng rituals among overseas Vietnamese, see Karen Fjelstad, 'We have lên đồng too: Transnational aspects of spirit possession', in Possessed by the spirits, pp. 95-110; and Karen Fjelstad and Nguyễn Thị Hiền, 'Lên đồng (spirit possession) as a transnational ritual', paper read at the conference on Approaching Vietnam's Contemporary Cultures: Methodology and New Studies, Hanoi, 2006.

22 Standing Committee of the National Assembly, Decree No 21/2004/PL-UBTVQH11, 18 June 2004. Item 1 of Article 3 states that 'the activities of folk beliefs are activities representing the veneration of ancestors, commemoration and honouring of those who had great merit towards the country and people; the veneration of spirits, traditional symbols and other activities of folk beliefs which are typical for good values in history, culture and social ethics'. 
does not frequent such places. One of my brothers, for example, said that his friends could not imagine that he has never gone to pray for his company. I was in the Buddhist pagodas and Tây Hồ Palace, a large Mother Goddess temple by West Lake in Hanoi, on the fifth day of the first lunar month in 2007. My impression was that the Palace was even more crowded than the Buddhist pagodas. One informant explained that Mother worship is closer to people's feelings and wishes. At the Palace they can pray to the Mothers and the Lords (male deities) about anything they Desire, from good health to success in business to a good education for their children. The crowd of bà đồng, ông đồng and lay people at the Palace indicates the depth and breadth of the belief in spirit possession after the 'decades-long domination of a secular, explicitly atheist ideology', as Oscar Salemink reaffirms. ${ }^{23}$

\section{Service to the pantheon and seats for spirits}

The Mother Goddess pantheon

Although the Mother Goddess religion is regarded by many as a genuinely Vietnamese popular religion, it is in fact a syncretic synthesis of indigenous beliefs and elements of imported institutional religions, including Indian Buddhism, Daoism and Confucianism. Mother Goddess religion is very much embedded in the local and historical context of Vietnam, but it also allows for the adoption of foreign elements and is reshaped in the process. The number of spirits is not fixed; generally, however, there are nine hierarchical ranks of spirits containing four non-indigenous spirits 'imported' from China, four Mother Goddesses, one Holy Father with his three royal Damsels and a Young Boy, 10 Mandarins, 12 Dames, 10 Princes, 12 Damsels, 10 or 12 Boy-Attendants and two animal spirits. There are thus a possible total of 70 or 72 spirits, including the 'imports': the Daoist Jade Emperor and the two Star Spirits, the Buddha, or Quan Âm (the Bodhisattva Avalokitesvara, known in Chinese as 'Guanyin' and in Japanese as 'Kannon'). ${ }^{24}$ The Viet can and do adopt new deities over time which are either legendary heros or historical figures, as in the case of the warrior-prince Trần Hưng Đạo. Despite the atheistic ideology of Marxism, moreover, the Viet have never stopped believing in the existence of spirits. The newest spirit that has come into the Mother Goddess religion is the figure of Hồ Chí Minh, whose statue is present in a number of temples today. ${ }^{25}$

Though Mother Goddess beliefs are primarily a religion of the Viet majority, many spirits have been borrowed from local ethnic groups in northern Vietnam, such as the Tày, Mường, Dao and Nùng. The religion also reflects the Viet cosmology of four realms: Heaven, Earth, Water and Mountains and Forests, each of which is governed by a different Mother Goddess. The four realms are symbolised by four colours: Heaven by red, Earth by yellow, Water by white and Mountains and Forests by blue/green.

23 Phan and Salemink, 'Ritual transformations', p. 11.

24 For overviews of these beliefs and practices, see Ngô Đức Thịnh, Đao Mẫu ở Việt Nam [Mother Goddess religion in Vietnam] (Hanoi: Văn hoá Thông tin, 1996); Ngô, 'The Mother Goddess religion: Its history, pantheon, and practices', in Possessed by the spirits, pp. 19-30; and Fjelstad, 'Mother Goddess religion'.

25 Nguyễn, 'Spiritual parents of the Viet'. On Trần Hưng Đạo see the various works by Phạm Quỳnh Phương: 'Trần Hưng Đạo', 'Hero and deity', and 'Tìm hiểu hiện tượng tín ngưỡng Đức Thánh Trần' [Study on the belief in Saint Trần] (M.A. thesis, Viện Văn hoá Dân gian, 1998). 
These four colours, along with various shades of pink, violet and brown, determine the colours not only of the costumes of mediums who are possessed by the spirits of the four realms, but also of their offerings to those spirits. ${ }^{26}$

'Lên đồng' has different interpretations; the word 'lên' means 'to rise', while 'đồng' 'might simply mean a possessed medium, that is a medium for some spirit or deity to enter him or her.' 'Lên đồng' is often called 'hầu bóng', in which hầu means 'to serve' and 'bóng' means 'spirit' or 'shadow'; scholars use the two terms interchangeably. ${ }^{27}$ Lên đồng, like spirit possession rituals elsewhere, is a complex religious and cultural performance which, as one scholar has written in another context, causes 'the supernatural' to be 'accomplished through theatrical means and dramatic interactions' ${ }^{28}$ The recognition of mediumship as a theatrical performance is not new in anthropology; many studies have demonstrated that possession is conducted as a dramatic form or a play that is composed of a series of scenes. ${ }^{29}$ Lên đồng ritual is not simply an aesthetic performance, a folk play or a ritual drama; rather, it is also a vivid representation of Viet culture displayed in front of the altar in a private shrine (cia điện) or a temple (đền). It must be accompanied by chầu văn, music and dance props. ${ }^{30}$ These performances are tailored for particular spirits, as they represent a spirit's idiosyncratic character. Spirit possession, John Beattie has said, 'is not just a form of religious undertaking, a way of coming to terms with and influencing the spirit world; it is (or may be) also a form of dramatic art in its own right'. The main ritual is the séance during which mediums perform and spirits descend or possess them. Here, theatre becomes reality, 'where spirits ... converse with men in human voices'. ${ }^{31}$ The séance resembles theatre in that both actors and mediums perform in harmony with musicians. As in theatre, the performance emerges from the harmony of the performers - religious masters, mediums and singers. Bà đồng and ông đồng, for their part, see the ritual as a service that they perform in order to fulfill their obligations and to be

26 Ngô Đức Thịnh, 'Lên đồng: Spirits' journeys', in Vietnam: Journeys of body, mind, and spirit, ed. Nguyễn Văn Huy and Laurel Kendall (Berkeley: University of California Press, 2003), pp. 252-72. 27 Nguyễn Khắc Khảm, 'Vietnamese spirit mediumship: A tentative reinterpretation of its basic terminology', Vietnam Forum, 1 (1983): 27-8 (quotation); see also Nguyễn Khẳc Khảm, 'Vietnamese mediums and their performances', Asian Folklore Studies Newsletter, 11 (1983): 11-21. On terminology see Nguyễn Thị Hiền, 'Religion of the Four Palaces'; Ngô Đức Thịnh, Đạo Mẫu; and Maurice Durand, Technique et panthéon des médiums viêtnamiens (Paris: École Française d'Extrême-Orient, 1959).

28 Peter J. Claus, 'Ritual performances in India', in Anthropology of religion: A handbook, ed. Stephen D. Glazier (Westport: Greenwood Press, 1997), p. 193.

29 See the discussions of mediumship as a dramatic performance in Laurel Kendall, 'Initiating performance: The story of Chini, a Korean shaman'; Carol Laderman, 'The poetics of healing in Malay shamanistic performances'; and Marina Roseman, "Pure products go crazy": Rainforest healing in a nation-state', in The performance of healing, ed. Carol Laderman and Marina Roseman (New York: RoutledgeCurzon, 1996), pp. 17-58, 115-42 and 233-70 respectively.

30 The term 'chầu văn' (literally, 'service literature/texts') refers to songs in honour of spirits (Norton, 'Vietnamese mediumship rituals', p. 93). The singing of chầu văn is a way of expressing thanks and reverence to the spirits; see Tô Đông Hải and Phạm Vãn Ty, 'Những khía cạnh văn hoá nghệ thuật của hát văn và hầu bóng' [Cultural and artistic aspects of văn songs and hầu bóng], in Hát văn [Văn songs], ed. Ngô Đức Thịnh (Hanoi: Văn hoá Dân tộc, 1992), pp. 42-50.

31 John Beattie, 'Spirit mediumship as theatre', Royal Anthropological Institute News, 20 (1977): 1-6; Edward Schieffelin, 'Performance and the cultural construction of reality', American Ethnologist, 2, 4 (1985): 707-24. 
blessed. How, then, are they regarded, and what are the reasons and motivations that led them to the religious path?

\section{'Spirit roots'}

Mediums perform the lên đồng ritual, making the spirits' journeys in imagination available primarily because they view it as their destiny to be mediums and expect their practice to bring them worldly and spiritual benefits. They perform to cure people, to enhance well-being and to obtain prosperity for themselves and for their clients (if they become master mediums). (A master medium [đồng trương] is an experienced medium who demonstrates his or her 'knowledge and social abilities' and whose fate is regarded as 'heavier than the fate of an ordinary mediums'.) ${ }^{32}$ The mediums humbly refer to themselves as 'seats' (ghế) upon which the spirits of Mother Goddess religion 'sit' $(n g u$ c). For many practitioners, lên đồng begins as a curiosity at first, but slowly becomes a joy and an entertainment and, finally, a 'religious need'. ${ }^{33}$ However, whether they are curious or find the ritual as a service, they all claim to have a 'spirit root' or destiny for mediumship.

Mediums ascribe their status to their possession of what is called in Vietnamese the 'root of mediumship' (căn đồng). 'Căn' has the sense here of a nature or basic character; in this context it also implies destiny. People whose basic character and destiny impel them towards mediumship are said to have a spiritual destiny (căn cao số đày). A spirit root may be either 'heavy' (năng) or 'light' (nhẹ). ${ }^{34} \mathrm{Nga}$ told me that those who possess a heavy or burdensome spirit root are said to have been touched by a certain spirit for a special life as a medium for that spirit. Being a medium is not easy; mediumship is, indeed, viewed as a burden. Before being initiated, mediums are said to experience a great deal of suffering in their lives; they may lose their health or go insane for no apparent medical reason.

People who possess a heavy or burdensome spirit root can be identified by master mediums or ritual masters (thầy cúng) based on their appearance and personality, which correspond to particular spirits. The manifestation of spirit roots in a person can vary according to that person's horoscope or personality, according to various informants. Such specialists also rely on a person's physiognomy and mannerisms in ascertaining which spirit root someone has; men and women may have the root of a spirit of either gender. ${ }^{35}$ Those who have a male spirit root are said to have glowing faces and red, restless eyes, hot tempers and an impulsive nature, while those who have a female spirit are said to be effeminate. A woman who is hot-tempered is considered by initiates to be 'manlike' (đàn ông); mediums might say that she has the Mandarin or Prince root (căn Quan or căn Ông Hoàng). By the same token, in public society, when a

32 Larsson and Endres, 'Children of the spirits', pp. 149-50.

33 Lê Hồng Lý, 'Tín ngưỡng lên đồng từ cái nhìn của người trong cuộc' [Lên đồng ritual from an insider's perspective], paper read at the International Conference on Mother Goddess Veneration and the Phủ Giầy Festival (Tín ngưỡng Thờ Mẫu và Lễ hội Phủ Giầy, Viện Nghiên cứu Vãn hoá Dân gian, Hanoi, 2001).

34 See the interpretations of 'căn' or 'căn năng' in Phạm Quỳnh Phương, 'Trần Hưng Đạo'; Fjelstad and Maiffret, 'Gifts from the spirits'; and Larsson and Endres, 'Children of the spirits'.

35 The gender issue is discussed in more detail in Norton, "Hot-tempered" women'. 
man looks effeminate, people say that he is 'womanlike' (đàn bà); in the context of spirit possession, mediums would say that he has a 'female spirit root' (căn cô).

People who possess the root of a certain spirit exhibit traits that correspond with that spirit's character or personality. Saying that a person has the 'Saint Trần' root (Thánh Trần, referring to Trần Hưng Đạo) means that he has a soldier-like carriage, and when possessed, garrottes his neck with a cloth. Sometimes he may pierce his cheeks and cut his tongue at a healing ritual or at the ritual of the anniversary of the Saint. ${ }^{36}$ If a woman has the Seventh Prince root, she has a male look and is strong in mind and character. Drugs intoxicate this spirit, as a chầu văn song dedicated to him says; thus the spirit smokes five or ten cigars at one time while performing. If a person has the Tenth Prince root, he is a real playboy, loafer and man about town. While possessed, the spirit sits very calmly, drinking alcohol and tea and enjoying the music of the chầu văn singers. A person with the Ninth Damsel root is possessed by a spirit guide of divination and can tell fortunes. Male mediums with this spirit root are addressed as 'Miss' ( $c \hat{)}$ ) by other mediums and are inclined to be effeminate; they have a frail carriage and walk coquettishly. A person with the young Damsel or BoyAttendant root is not mature and behaves like a little boy or girl, amusing the audience with childish antics and mannerisms while performing.

Based on the life stories and other information from my sources, I have observed various afflictions including knotted hair disease, insanity and hysteria, spontaneous trances, poor physical health, misfortune in life and the exceptional motivation that is merely for worldly benefit. It should be noted that individuals often become initiates because of a combination of symptoms or motivations. The stories below will reveal what lies behind the performers in an attempt to uncover the ways in which they move down the path from curiosity - or, often, desperation - to religious necessity.

\section{Shared life stories of bà đồng and ông đồng}

Knotted hair and insanity

A visitor to the shrine of the Mother Goddess religion who has the chance to talk with a great master (especially the female owner of a shrine) will probably be told about her life as a victim of either knotted hair (kêt tóc) disease or hysteria, and about patients with similar afflictions that she has cured during her practice. ${ }^{37}$ The life story of Sister Nga is one of the most interesting I recorded during my field research in the countryside of Hưng Yên province, close to Hanoi. Nga provided me with compelling information about her vocation as a master medium and her views on the Mother Goddess religion, to which she has devoted her life. 'If I stopped practising lên đồng rituals,' Nga said, 'I would become the victim of a "false illness" (ốm dỏ), causing a loss

36 Phạm Quỳnh Phương, 'Hero and deity', pp. 41-3.

37 During my childhood I heard about villagers who suffered from a mysterious disease called knotted hair (kết tóc) but thought it was a myth. A victim's hair would become knotted in bunches that could not be combed out; if they shaved their heads, it was said that they would go mad or die. The cure for the malady involved, in a sense, giving in to the causes of the disease. The victim could sponsor rituals performed by someone who knew how to cure the disease - that is, a master medium who was highly gifted spiritually. 
of appetite; I would drink only water and eat some fruit.' She was also afflicted with knotted hair. Nga described her transformation:

Suddenly, I was ill, very ill. My hair was matted and not combed out, but I could not untangle it. I went to a hospital, but I was not cured. I took various Western medicines, but I didn't recover. At that time people were not religious as they are nowadays. My parents-in-law did not believe in magico-religious healing, and my husband's family was very poor. Fortunately, my biological mother came to see me. She took me to an astrologist, and it turned out that I have a burdensome spirit root. The prophet predicted that if I did not go to a spirit medium for an initiation, I would die in water, in a river. He told me that I was being punished (bị hành) [by spirits], but I didn't understand what that meant at that time. Anyway, my mother borrowed money for sponsoring the initiation. After the ritual, I felt much better; I had a good appetite, slept well, and felt very happy. ${ }^{38}$

This is a common story in many ways. Many mediums are originally the patients of other mediums and in general, mediums see themselves as afflicted, in a sense, by a spiritually generated malady, sometimes referred to as a ' $y i n$ ' (Viet. $\hat{a} m$ ) disease. In Viet culture a yin disease is caused by supernatural forces in the Viet culture and is diagnosed by diviners or mediums, whereas doctors of Western medicine diagnose the causes of yang (Viet. duong) diseases. This is a folk classification, similar to the dichotomy of 'natural' and 'supernatural' in Western discourse or, in Laderman's work, 'usual' and 'unusual' sickness. ${ }^{39}$ The indications of yin disease vary; it can be an unexplainable change in character - insanity, knotting of the hair or what is known as a fake illness. These diseases are all seen as indications of having a heavy spirit root, the root of mediumship. Patients may have terrible dreams of having a meeting with a spirit, seeing a snake, a leech, or travelling to an invisible world. They may have knotted hair, whereby their hair becomes tangled and dirty for no apparent reason. They may become hysterical and exhibit symptoms of 'insanity', wandering around aimlessly and talking nonsense. Such people, as they themselves see it, ultimately become mediums for reasons of self-preservation. Patients with knotted hair disease or some other spiritual health problem can be cured only if they have strong beliefs in the power and compassion of the spirits (thánh thuoong) and in the sincerity of their own hearts (thành tâm), as Nga explained to me. Otherwise, they would endure their physical problem for their entire lives. ${ }^{40}$

Nga's story is common among female mediums whom I have encountered. Thắm in Hà Đông town and Sang in a village outside Hanoi all experienced knotted hair, insanity and agitation. Their initiation has restored the balance in their lives as well as their physical health, while enabling them to improve their lives by making ritual objects for their rituals and for their clients' needs. Sang's status was raised from a

38 Field notes, 1998.

39 Nguyễn Thị Hiền, 'Religion of the Four Palaces', ch. 5, discusses yin diseases. See also Carol Laderman, Taming the wind of desire: Psychology, medicine, and aesthetics in Malay shamanistic performance (Berkeley: University of California Press, 1991), p. 15.

$40 \mathrm{Nga}$ observed that there are a number of individuals who suffer from what is called spirit root but do not know how to be treated (field notes). 
pitiful trash collector to a fairly wealthy businesswoman, while Thắm could now make enough money for her family to live on by successfully selling noodles in the Hà Đông market. ${ }^{41}$

As mentioned above, the manifestations of a heavy spirit root are often found among a constellation of symptoms. What the Vietnamese call 'insanity' (điên), such as that experienced by Nga and Thắm, encompasses a range of symptoms including disorientation, uncontrollable impulses, speaking in gibberish and aimless wandering. People who fall into hysteria think of themselves as spirits such as the Tenth Prince, the Seventh Prince, the Third Damsel, the Ninth Damsel or even, on occasion, their own ancestors. Individuals may believe that they have supernatural powers and tell their family members and neighbours to show respect by doing what they command and by praying to them. In their hysterical state, they may sometimes go naked and soak in a pond or a river. These symptoms are almost as common as knotted hair and apply to female mediums. Such people will usually refuse to go to a hospital for treatment, believing that they can only be cured if their families take them to a master medium for a healing ritual in a Mother Goddess religion temple.

For an ông đồng, the typical case of heavy spirit root is insanity. Thắng, who lives not far from Hanoi in the Văn Giang district of Hưng Yên province, is one of the insane patients whom Nga has cured. He was a soldier and a non-believer whose religious life revolved around the veneration of his ancestors and other deceased people. Since his cure, Thắng has become a medium, devoting his life to the spirits. After getting to know him, Nga offered to perform an initiation ritual for him because she was certain that the spirits were causing his symptoms. Although his family was very poor and could not afford the ritual, she paid for it with her own money, on condition that he would repay her later. After the first ritual, his condition improved, and in a short time he recovered completely. Since then he has been like Nga's adopted child and goes to her shrine whenever she performs a ritual, acting as a hầu dâng, an assistant who helps the medium handle props and put on costumes during rituals.

In a private conversation, Thắng expressed pleasure with his secular life of working in the rice fields and cultivating mandarin orange trees to sell during the New Year and also with his spiritual life as Nga's assistant. However, he complained about being so busy serving her as hầu dâng and about having to be resigned (nhẫn nhuc) to being scolded when he was not available to perform this role. ${ }^{42}$ Unlike the fine lives of the master mediums, Thắng's life is still hard because he is struggling to earn a living to support his family. It can be said, however, that the religious path of initiating to be an ông đồng has cured his insanity and helped him to find equilibrium in his life.

41 Information from field notes, 2001. The income derived by Nga's family members from producing votive offerings is discussed in Nguyễn Thị Hiền, "'A bit of a spirit favor is equal to a load of mundane gifts": Votive paper offerings of lên đồng rituals in post-Renovation Vietnam', in Possessed by the spirits, pp. $127-42$.

42 The resentment of overseas Vietnamese upon seeing a master medium give a hard kick to a female hầu dâng is mentioned in Karen Fjelstad, 'A tale of two temples: Transnationalism and the views of a traveling spirit' (unpublished manuscript, 2006). 


\section{Spontaneous trances}

Many of those initiated into the spiritual order were previously afflicted with spontaneous possession whenever they entered a temple. People exhibiting these symptoms will regularly go into a trance, dancing semi- or un-consciously, until a master medium begs the spirits to be compassionate (thwong) and release (tha) the victim. I have observed people in a trance dancing together during festivals at Mother Goddess religion temples in Kiếp Bạc (Hải Dương province) and Phủ Giầy (Nam Định province). The spontaneously possessed are described by other practitioners as having been 'grabbed' (bi bắt sát) or 'punished' (bi hành) by the spirits, or as being haunted, in a sense, by a 'self-pitying shadow' (tủi bóng), a spirit who haunts a particular person until he or she yields and undergoes initiation.

Informants I met at the Kiếp Bạc festival complained about their fate, saying that 'being grabbed [by a spirit] is miserable' (bị bắt sát khổ lắm). They enter temples and shrines to worship like other lay people, but leave exhausted, having sometimes endured hours of dancing in a trance state. Yet, the trance is something they also value - it is, in a sense, both a blessing and a curse. Sometimes those suffering spontaneous trances want to go to these places but hesitate because the trance makes them so tired afterwards. The way to be freed from this situation is through a master medium, who performs an initiation ritual for the victims, and eventually they enter a trance only during lên đồng rituals.

Nga explained to me that these people are the spirits' children (con của các ngài), but that they 'do not know the way' (không biết lối) to serve the spirits, so the latter come down to take them into their order. They are possessed by spirits, enter trances without control, dance madly or cry bitterly, and regain consciousness after a while, either by themselves or as a result of the prayer of a master medium. Some people who go into spontaneous trances exhibit biophysical symptoms; they feel dizzy and go into a kind of self-hypnotic state when they enter a temple or a shrine, a state seeming triggered by the environment itself, full of incense smoke and spirits' statues. They are similar to people who spontaneously faint at funerals or the sight of blood or who enter a trance while watching some spectacular event. Perhaps it is also because they seem to have a strong religious belief that they are 'grabbed' by a spirit - that is, that they are potential physical bodies for spirits.

Loan, a sister-in-law of one of my high-school classmates, used to suffer from possession by the Ninth Damsel spirit. One day in the summer of 1998, she went to a Hanoi temple dedicated to Trần Hưng Đạo while a lên đồng ritual was being performed by a medium whom she did not know. When possessed by Saint Trần, he conveyed the message that Loan had been punished for seven years, and that she had sometimes suffered from insomnia and could not fall asleep for seven nights at a time. She had to perform a ritual of thanksgiving ( $(\tilde{e}$ ta $)$ to ask the spirits for remission and for mercy. She then went to see a master medium named Oanh in Xuân Đỉnh commune, Hanoi, for consultation. He merely told her fortune, for the day of her initiation had not yet come. In other words, she was still in the ordeal period and was to be tested for her patience and her faithfulness to the spirits to see whether she would be a gifted spiritual medium in the future.

The Ninth Damsel possessed Loan often and eventually told her that on the fourth day of the first lunar month of 2000 she should perform a ritual of farewell for the 
spirit at a shrine in her home village in Thái Bình province. I attended this ritual together with two colleagues from the United States and Sweden, even though it was held during the Lunar New Year holiday. During the ritual, the spirits of the Mother Goddess religion enlightened her and bestowed prophetic abilities upon her. As a result, since the ritual she says that she can now control her trance, entering it only when she asks the spirits to incarnate within her. Even though she has not been truly initiated as bà đồng, in some aspects she is serving spirits as her own way of praying for 'release' at the altar at her home and at public temples. By doing this, she can manage to have a 'normal life', as she says, and be blessed with a good job teaching English at a university in Hanoi.

\section{Physical health problems}

A number of possessed people suffer from what is referred to - perhaps because it is ascribed to spiritual and not biological causes - as 'petty illness' (óm văt) or 'false/ pretend illness' (ốm giả vò). Despite the name, people with this illness do become genuinely sick and lose their appetite. They may also have disturbing dreams about climbing trees, seeing snakes or going to Mother Goddess temples and performing lên đồng rituals. They may go to see doctors, but it is no use: doctors cannot diagnose their disease. Eventually they seek a spiritual solution: through friends and acquaintances, they will consult a master medium, who advises them to practise the Mother Goddess religion and become 'seats' for the incarnating spirits. They are told that if they do, their problems will be over and their health will return. These people eventually become interested in lên đồng rituals, take part in them and make pilgrimages to the Mother Goddess temples with friends and mediums. After a while, they may choose a master medium and go through an initiation ritual.

Tuyết, from a village outside of Hanoi, is a typical case of someone who suffered physical ailments and was eventually initiated. She reports that she felt cold inside; her feet were so cold that they felt dead. She went to a hospital, but the doctors there could not tell her what was wrong with her. She went to pray in various temples and her health got better. Finally, she got to know a great medium named Ngọc through a neighbour who was one of Mrs Ngoc's disciples. The medium agreed to help by performing an initiation ritual at Tuyết's temple in Hanoi. From then on, her health problems disappeared, and her business of raising fish and trading in small items improved greatly. Since then, she has followed Ngọc - that is, she frequently goes to the medium's shrine for prayers and takes part in her master's practices. Thus, her mediumship not only has helped her to get over the petty illness, but has also brought her good business. She is very happy to show off her newly built house but still worries that it will be difficult for her children to enter universities. She hopes that with her efforts to make money and serve the spirits, all will be well for her children.

\section{Worldly benefit}

Since the advent of Đối Mới increasing numbers of people have come to expect good fortune, good business or good health through supernatural support, as well as through their own abilities. This category of mediums includes a great number of educated cadres, businesswomen and businessmen in urban areas, as these are the sorts of people who can afford the relatively lavish rituals. Their businesses are high-risk in 
comparison with farmers, workers and administrators, who receive salaries from the government. They believe that their business fortunes partly depend on whether or not they have blessed gifts (lộ, meaning good luck or good fortune), and these gifts may depend upon whether or not they serve the spirits (hầu thánh) appropriately. In their uncertainty, they seek these blessed gifts - help, mercy, and compassion from spiritual powers; an easing of their risk; and general success in business.

This sort of attraction to the Mother Goddess religion is not really new and may explain why such a large number of important temples are located in Lang Sơn province, not far from the main roads that lead to important Sino-Vietnamese border trading area. ${ }^{43}$ The provincial capital, the town of Lang Sơn, has long been a commercial and trading centre for the two countries; it is situated between Hanoi and the Chinese border, a location that is both accessible and convenient. Thus, business people from both sides of the frontier often trade goods through the Lạng Son Pass.

Many female vendors at the Đồng Xuân and Hôm Markets in Hanoi practice lên đồng rituals. There are two famous temples - the one on West Lake (Hồ Tây) mentioned above and one on Hàng Quạt Street - where business people perform their rituals. The first case is that of Tuất, who lives in Hanoi. She used to be a very successful businesswoman, trading foreign cigarettes and Chinese goods, but after a series of misfortunes she came to the religion. She was the head of a trading group that sold cigarettes restricted by the government and became very wealthy, but her luck changed over time as she encountered more and more trouble both personally and in her business. She had two husbands who died prematurely and suddenly, and one day in 1989, she was caught by police with 3,000 packages of cigarettes in her car and feared she could be convicted for smuggling. She had to sell all of her property, including seven houses in Hanoi, in order to pay the 'fine' (actually a bribe to the local officials) for herself and her partners in lieu of a jail sentence. Shortly thereafter, her son died in an accident. She was miserable and wanted to commit suicide.

One of Tuất's friends introduced her to a master medium in Thanh Trì district outside of Hanoi; he told her that she must serve the spirits. When she met the master, she hugged him - an unusual act in Vietnamese culture, especially when meeting someone for the first time. As she explained, that meant that she felt she had found a master who could help her overcome her troubles. After her initiation ritual, her life and business began to improve steadily, and she was earning enough money to raise her four children. Tuất now trades Chinese goods from Lạng Sơn to Hanoi; she only uses a part of her earnings for her family, reserving a good portion to sponsor rituals and for donations to temples. The religious service and faith help her to overcome her grief at the death of her family members and to have a balanced life in terms of her business and family.

The other case I will present here is Liên in Khoái Châu district, Hưng Yên province. She is very wealthy, a successful trader of mint and basil oils. She told me that before being initiated she had gone insane, wandering aimlessly around her village and soaking herself in ponds; thus she could not keep up her business. She was brought to a

43 The principal temples dedicated to the Mother Goddess, Second Mandarin, Second Dame, Fifth Dame, Sixth Dame, Youngest Dame and Youngest Damsel of Mountains and Forests realm are all located in Lạng Sơn province. 
spirit medium named Tang in a neighbouring commune for healing and was then taken through an initiation ritual. Since then, she says that she has been very lucid. More relevant to the subject of this section, she affirms that because of her service to the spirits, her business is better than ever. Her business depends on unstable local supplies of the oils; the price may rise sharply in just a few days one month and go down just as sharply in the next. Liên sometimes has dreams about selling all of her oils right away, or about buying and saving them in her stock at home. She understands these dreams to be messages from the spirits, guiding her in her business. Sometimes, for example, she dreams of 'cháy chọ' (literally, a market on fire), meaning that goods in the market are sold out. She then anticipates that in several days, oils will be rare and the price will go up; the following day, she goes out to buy as much oil as possible. Liên says that she has made a lot of money this way. Her story is as interesting one, for it is one of numerous cases when the spirit mediums strongly believe that their religious path brings them wealth and advancement and limits misfortune. ${ }^{44}$

\section{Conclusion}

The informants discussed here, who have suffered from knotted hair (Nga and Thắm), had mental and physical problems (Thắng and Tuyết) or are now wealthy people (Tuất, Ngọc and Liên), have regained a stable life and physical health and are blessed in life with a successful business after being initiated. ${ }^{45}$ One thing that makes them different from lay people is the decision to become 'seats for spirits to sit upon', to perform lên đồng rituals for their whole lifetime. These individuals, however, are neither 'crazy' nor 'unstable', they only temporary experience insanity or instability while on the path to becoming mediums. People are thus motivated to become mediums to find well-being, harmony and good fortune in life. For a number of them, religious beliefs pervade their daily lives. They throw two coins in front of the Mother Goddess altars as a means of divination to check their daily work, they put fresh flowers and cups of fresh water on the altars, and they light incense to the spirits on a daily basis. They even use expressions like 'Oh, my Mother!', '[I] pray to my Mother' or '[I] pray to my Lord' in their daily speech.

My article demonstrates that they are not strange, superstitious or hot-tempered fools with a liking for colourful and odd clothes as most people perceive; rather, they are practitioners of a complex and increasingly important and popular religious system. For the practitioners of this religious path, their initiation and ritual performance are seen as granting vital and even life-saving benefits and blessings, good health and good fortune. They see themselves as children of the spirits, serving their

44 In recent years it has become common for business people and educated people to either undergo initiation rituals or else have rituals performed by mediums for the purpose of being blessed. This phenomenon, which has become even more widespread since the 2004 ordinance on the veneration of spirits, has been studied by researchers; See Lê Hồng Lý, 'Tín ngưỡng lên đồng' and Andres, 'Spirit performance'.

45 This article does not examine cases of mediums who have followed a religious path yet still suffer from either mental or worldly problems. One such example is my cousin, who was unable to improve her business of trading goods in her home village; she still suffered from her 'misfortune' until she quit doing business; she now spends all of her time serving the spirits by building a shrine and 'opening a palace' ( $m o ̛$ phủ, referring to the performance of rituals) for her clients. 
spiritual parents and other deities through the initiation and regular service. More importantly, performing lên đồng rituals fulfils the mediums' religious needs, providing them social and emotional satisfaction that they can find nowhere else and - for some bringing them good luck and prosperity in their life and business. 